дования 2016 г.: Болгар и Свияжск. Казань: ИД «Казанская недвижимость», 2016. С. 24-25.

10. Обломский А.М., Козмирчук И.А. Поселение позднеримского и гуннского времени Ксизово-19 // Острая Лука Дона в древности. Археологический комплекс памятников гуннского времени у с. Ксизово (конец IV-V в.) Раннеславянский мир. Выпуск 16. М.: ИА РАН, 2015. С. 75-133.

11. Скарбовенко В.А. Отчет о раскопках селища Севрюкаево II в Ставропольском районе Самарской области в 2003 году. Самара, 2003 / Научный архив археологической лаборатории Самарского государственного университета.

\title{
TECHNOLOGICAL FEATURES OF CERAMIC COMPLEX OF 2ND FOURTH OF I MILLENNIUM AD OF SOSENKI SETTLEMENT IN THE ULYANOVSK REGION
}

(C) 2017

Nikitina Anna Valerievna, postgraduate student of Sociology, Politology and Russian History Department Samara State Technical University (Samara, Russian Federation)

Abstract. The following paper deals with typological and technological analyses of the pottery of the Sosenki settlement of the Ulyanovsk region. The author identified 3 morphological groups of vessels among the available material on the basis of external features that are based on vessels shape and surface treatment. Technical-andtechnological analysis of ceramics, based on the methods of A.A. Bobrinsky, was carried out for the purpose of determining the characteristics of the initial raw material, traditions of composing the pasts and the character of the calcination of the vessels. The analysis of the preparatory stage of the pottery process confirmed the presence of some differences in the selected groups mainly related to the features of the dimension and calibration of grog in the paste. In conclusion, it is proposed to assign this complex to the Upper Don cultural traditions. However, it is pointed out that a very limited amount of material still requires only the introduction of a scientific use without focusing on cultural interpretations. Settlement dating based on mass material can not be determined smaller than within the C2-D2 phases. The settlement dates back to the pre-Imenkovo period and materials may find later echoes on the sites of Samara Bend.

Keywords: Late Roman period; D2 period; Great Migration period; ancient pottery; historical-and-cultural approach of ceramics study; method of A.A. Bobrinsky; technical-and-technological analysis of ceramic; Middle Volga region; archeology of Ulyanovsk region; Staromaynsky district; Uren river; Forest-steppe area.

УДК 902/904 (903.02)

Статья поступила в редакцию 18.06.2017

\section{НЕКОТОРЫЕ ИТОГИ ПЕТРОГРАФИЧЕСКОГО ИССЛЕДОВАНИЯ КЕРАМИКИ С ПОСЕЛЕНИЯ ТОКСАНБАЙ}

(C) 2017

Шевнина Ирина Викторовна, научный сотрудник археологической лаборатории

Костанайский государственный университет им. А. Байтурсынова (г. Костанай, Республика Казахстан)

Лошакова Татьяна Николаевна, старший научный сотрудник

Институт археологии имени А.Х. Маргулана (2. Алматы, Республика Казахстан)

Аннотация. Исследование посвящено изучению исходного сырья и формовочных масс керамических изделий с поселения Токсанбай. Целью исследования являлось изучение технологических аспектов при изготовлении керамических сосудов, углубленное изучение исходного сырья и формовочных масс керамики гончаров поселения. При исследовании образцов, кроме петрографического анализа, фрагменты керамики изучались с использованием метода бинокулярной микроскоскопии, проведены химические опыты (микрометодом) с применением молибдена аммония и соляной кислоты, проверены микрореакциями на железо в составе черепка. Полученный результат выявил, что исходным сырьем служила ожелезненная глина, а химическая реакция на Fe всех фрагментов оказалась положительной. Исходная глина запесоченна, кроме этого в составе песка отмечены полевые шпаты, обломки песчаников, окремненных сланцев и эпидот. Выявлено три рецепта формовочных масс. Органика фиксируется в виде окремненных пустот. Состав органики определен, как карбонатно-кремнистый или карбонатно-фосфатный. Анализ на микрореакции с применением молибдена аммония $\left(\mathrm{MoH}_{4}\right)_{2} \mathrm{AmO}_{4}$ определил наличие в образцах органики фосфатного типа. Из органических наполнителей у части исследуемых образцов были выявлены пустоты округлой и овальной формы от выгоревшей органики. Исследование керамики поселения будет продолжено, но можно утверждать, что токсанбайские гончары использовали местную глину, а самой распространенной примесью являлся органогенный известняк. 
Ключевые слова: поселение; Токсанбай; плато Устюрт; чинк; формовочная масса; керамика; техникотехнологический анализ; петрографический анализ; бинокулярная микроскопия; молибден аммония; карбонат; микрореакция; ожелезненная глина; полевой шпат; органогенный известняк; окремненные сланцы; дресва; эпидот; шлиф; естественная примесь; гидрослюда; рецепт формовочной массы; реликт раковин; биогенные остатки; спикулы губок; брахиоподы.

Керамика на поселениях не только один из самых массовых материалов, но и один из важнейших артефактов. Она выступает культуроопределяющим маркером древних сообществ, хранителем сакральной информации оставленной в орнаменте, источником изучения технологических особенностей керамического производства. Методы исследования керамики совершенствуются и дают возможность более детально изучить разного рода аспекты керамического производства. Изучение минералого-геохимического состава керамики приобрело особую важность для исследования древнего производства изделий из глины $[1 ; 2]$. Применение этого метода дает возможность количественно установить минеральный и химический составы формовочной массы, выявить технологические приемы изготовления, идентифицировать источники сырья. В совокупности это расширяет знания о древнем керамическом производстве и дает представление о технологических традициях в изготовлении керамики, что в свою очередь позволяет по-новому взглянуть на археологические комплексы. Петрография древней керамики является одной из ценных аналитических техник для современного изучения керамики. Она применяется для определения структуры глинистых материалов, исследуя ее в тонких срезах под микроскопом.

Материалы, полученные при исследовании поселения Токсанбай, неоднократно находили отражение в публикациях. Первые исследования на памятнике были осуществлены Западно-Казахстанской археологической экспедицией Института археологии им. А.Х. Маргулана под руководством 3. Самашева, в 1997 г. [3], и планомерно продолжены с 2004 года [4; $5 ; 6]$. Отдельные исследования были посвящены орудиям труда и медеплавильному производству поселения [7], домостроительным традициям [8], деталям колесничной упряжи [9]. Ранее авторами уже предпринимались исследования керамики с поселения Токсанбай [10] и данная работа, посвященная изучению исходного сырья и формовочных масс керами- ческих изделий с применением петрографического анализа, является логическим продолжением этих исследований.

При помощи технико-технологического анализа были изучены 16 целых и частично реконструированных сосудов, фрагменты венчиков (16 экз.), крупные фрагменты стенок (4 экз.) и донных частей сосудов (4 экз.).

Целью исследования является продолжение изучения технологических аспектов при изготовлении керамических сосудов и углубленное изучение исходного сырья и формовочных масс керамики гончаров поселения Токсанбай.

Для анализа было отобрано 16 фрагментов керамики. Кроме петрографического анализа фрагменты керамики дополнительно изучались при помощи метода бинокулярной микроскопии. Петрографический анализ выполнен в петрографической лаборатории отдела вещественного состава ОАО «Кустанайская поисково-съемочная экспедиция» петрографами О.В. Карзановой и Е.Н. Мирошниченко. Кроме этого, были проведены следующие химические опыты с применением микрометода:

1) анализ с применением молибдена аммония $\left(\mathrm{MoH}_{4}\right)_{2} \mathrm{AmO}_{4}$ показывает наличие или отсутствие фосфатов, при взаимодействии с карбонатосодержащим черепком дает желтый цвет;

2) анализ с соляной кислотой $\mathrm{HCl}$ показывает наличие или отсутствие карбоната.

А также все фрагменты дополнительно проверялись микрореакциями на железо в составе черепка.

Исходным сырьем токсанбайским гончарам служила ожелезненная (гидроокислы железа - гематит и лепидокрокит) глина (гидрослюда с примесью монтмориллонита и каолинита) (табл. 1). Химическая реакция на $\mathrm{Fe}$ всех фрагментов оказалась положительной. В ряде случаев петрографами зафиксированы вкрапления железистых бобовин. Также в глине петрографы отмечают примесь углистого состава.

таблица 1 - Петрографическое описание образцов с поселения Токсанбай

\begin{tabular}{|c|c|c|c|c|c|c|c|c|c|c|c|c|c|}
\hline 1 & 2 & 3 & 4 & 5 & 6 & 7 & 8 & 9 & 10 & 11 & 12 & 13 & 14 \\
\hline 1 & $\frac{\frac{1}{2}}{\frac{1}{n}}$ & $\begin{array}{l}\text { Псе- } \\
\text { фито- } \\
\text { псам- } \\
\text { моале } \\
\text { вро- } \\
\text { пели- } \\
\text { товая, } \\
\text { вкрап } \\
\text { лен- } \\
\text { ная }\end{array}$ & $\begin{array}{l}\text { менее } 0,01- \\
40 \\
0,01-0,1-14 \\
0,1-0,25-20 \\
0,25-0,5-10 \\
0,5-1-7 \\
1-1,5-2 \\
1,5-2-3 \\
2,0-2,5-2 \\
2,5-3,0-2\end{array}$ & $\begin{array}{l}\text { Однород- } \\
\text { ная в от- } \\
\text { дельных } \\
\text { участках } \\
\text { сегрега- } \\
\text { ционная, } \\
\text { сгустко- } \\
\text { вая, гнез- } \\
\text { довидная, } \\
\text { волокни- } \\
\text { стая }\end{array}$ & $\begin{array}{l}\text { Кв-25 } \\
\text { Пш-3 }\end{array}$ & $\begin{array}{l}\Gamma+ \\
{ }^{+}+ \\
0 \\
(\mathrm{H})\end{array}$ & \begin{tabular}{|l} 
Гидрослюда \\
с примесью \\
органики и \\
гидроокислов \\
железа (ре- \\
акция на Fе \\
положитель- \\
ная) и желе- \\
зистого крип- \\
тозернистого \\
материала
\end{tabular} & - & - & $\begin{array}{l}30 \\
\text { (из орга- } \\
\text { ногенно- } \\
\text { го из- } \\
\text { вестняка, } \\
\text { округлой } \\
\text { формы) }\end{array}$ & $2-3$ & $\begin{array}{l}\text { до } \\
10\end{array}$ & $\begin{array}{l}\text { Обломки фосфат- } \\
\text { но-карбонатной } \\
\text { органики. Релик- } \\
\text { ты микроорганиз- } \\
\text { мов в биоморф- } \\
\text { ном состоянии в } \\
\text { обломках органо- } \\
\text { генного известня- } \\
\text { ка }\end{array}$ \\
\hline
\end{tabular}


Шевнина И.В., Лошакова Т.Н.

Некоторые итоги петрографического исследования керамики..

07.00.00 - исторические науки и археология

\begin{tabular}{|c|c|c|c|c|c|c|c|c|c|c|c|c|c|}
\hline 2 & 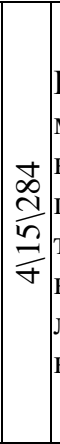 & $\begin{array}{l}\text { Псам } \\
\text { моале } \\
\text { вро- } \\
\text { пели- } \\
\text { товая } \\
\text { вкрап } \\
\text { лен- } \\
\text { ная }\end{array}$ & $\begin{array}{l}\text { менее } 0,01- \\
45 ; \\
0,01-0,1-18 ; \\
0,1-0,25-10 ; \\
0,25-0,5-15 ; \\
0,5-1-7 ; \\
1-1,5-2 ; \\
1,5-2-2\end{array}$ & $\begin{array}{l}\text { Неравно- } \\
\text { мернозер- } \\
\text { нистая } \\
\text { сгустко- } \\
\text { ватоя, в } \\
\text { отдель- } \\
\text { ных } \\
\text { участках } \\
\text { тонко- } \\
\text { плойчатая }\end{array}$ & $\begin{array}{l}\text { Кв-30 } \\
\text { Пш-1 } \\
\text { гема- } \\
\text { тит }\end{array}$ & $\begin{array}{l}\Gamma+д \\
+ш \\
+\mathrm{O} \\
(\mathrm{H})\end{array}$ & $\begin{array}{l}\text { Гидрослюди- } \\
\text { сто-углистая } \\
\text { масса с при- } \\
\text { месью орга- } \\
\text { ники и монт- } \\
\text { морилонита } \\
\text { и гидроокис- } \\
\text { лов железа } \\
\text { (реакция на } \\
\text { Fе положи- } \\
\text { тельная) }\end{array}$ & $\begin{array}{c}\text { до } \\
5\end{array}$ & 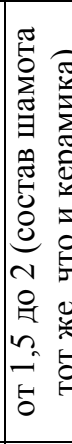 & $\begin{array}{l}\text { до } 30 \\
(\text { из орга- } \\
\text { ногенно- } \\
\text { го из- } \\
\text { вестняка, } \\
\text { остро- } \\
\text { уголь- } \\
\text { ной, вы- } \\
\text { Тянутой } \\
\text { формы) }\end{array}$ & \begin{tabular}{|c|} 
от \\
0,5 \\
до \\
$2,2,5$
\end{tabular} & до 8 & $\begin{array}{l}\text { Обломки фосфат- } \\
\text { но-карбонатной } \\
\text { полидетритовой } \\
\text { органики } \\
\text { (органика заме- } \\
\text { щена карбонатом). } \\
\text { Реликты микроор- } \\
\text { ганизмов в об- } \\
\text { ломках известняка } \\
\text { (обломки члени- } \\
\text { ков, криноидей, } \\
\text { брахиоподов) } \\
\end{array}$ \\
\hline 3 & 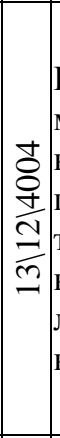 & $\begin{array}{l}\text { Псам } \\
\text { моале } \\
\text { вро- } \\
\text { пели- } \\
\text { товая } \\
\text { вкрап } \\
\text { лен- } \\
\text { ная }\end{array}$ & $\begin{array}{l}\text { менее } 0,01- \\
20 ; \\
0,01-0,1-20 ; \\
0,1-0,25-20 ; \\
0,25-0,5-20 ; \\
0,5-1-15 ; \\
1-2-3 ; \\
2-2,5-2\end{array}$ & $\begin{array}{l}\text { Однород- } \\
\text { ная тон- } \\
\text { козерни- } \\
\text { стая, } \\
\text { участками } \\
\text { неодно- } \\
\text { родная }\end{array}$ & $\begin{array}{l}\text { Кв-5 } \\
\text { Пш-1 }\end{array}$ & $\Gamma+\Omega$ & \begin{tabular}{|l} 
Гидрослюди- \\
сто-углисто- \\
глинистого \\
состава \\
(реакция на \\
Fе положи- \\
тельная)
\end{tabular} & - & - & \begin{tabular}{|l|}
55 \\
(из орга- \\
ногенно- \\
го из- \\
вестняка \\
угловато- \\
окатан- \\
ной фор- \\
мы)
\end{tabular} & $\begin{array}{c}2 \times 2 \\
1,25 \\
\times 1,5 \\
1 \times 1\end{array}$ & - & $\begin{array}{l}\text { Фосфатно-карбо- } \\
\text { натной полидет- } \\
\text { ритовой органики } \\
\text { (органика заме- } \\
\text { щена карбонатом). } \\
\text { Реликты микроор- } \\
\text { ганизмов в об- } \\
\text { ломках известняка } \\
\text { (обломки членни- } \\
\text { ков, лилий-крино- } \\
\text { идей, брахиопо- } \\
\text { дов, мшанок) } \\
\end{array}$ \\
\hline 4 & m. & $\begin{array}{l}\text { Псам } \\
\text { моале } \\
\text { вро- } \\
\text { пели- } \\
\text { товая } \\
\text { вкрап } \\
\text { лен- } \\
\text { ная }\end{array}$ & $\begin{array}{l}\text { менее } 0,01- \\
45 ; \\
0,01-0,1-20 ; \\
0,1-0,25-8 ; \\
0,25-0,5-14 ; \\
0,5-1-8 ; \\
1-2-2 ; \\
2-2,5-2\end{array}$ & \begin{tabular}{|l|} 
Неравно- \\
мернозер- \\
нистая, \\
сгустко- \\
вая, в от- \\
дельных \\
участках \\
волни- \\
стая, \\
гнездо- \\
видная
\end{tabular} & \begin{tabular}{|l|} 
Кв-25 \\
Пш-2 \\
гема- \\
тит 2 \\
об- \\
ломки \\
пес- \\
чани- \\
ков и \\
слан- \\
цев - \\
5 \\
\end{tabular} & $\begin{array}{l}\Gamma+д \\
+\amalg \\
+\mathrm{o} \\
(\mathrm{H})\end{array}$ & $\begin{array}{l}\text { Гидрослюди- } \\
\text { сто-углистая } \\
\text { масса с при- } \\
\text { месью орга- } \\
\text { ники и монт- } \\
\text { морилонита } \\
\text { и гидроокис- } \\
\text { лов железа } \\
\text { (реакция на } \\
\text { Fе положи- } \\
\text { тельная) }\end{array}$ & 5 & $\begin{array}{r}0,8 \\
3\end{array}$ & \begin{tabular}{|l}
20 \\
(из орга- \\
ногенно- \\
го из- \\
вестняка \\
угловато- \\
окатан- \\
ной фор- \\
мы)
\end{tabular} & \begin{tabular}{|c|} 
до \\
$0,5-$ \\
3
\end{tabular} & $\begin{array}{c}\text { до } \\
8-10\end{array}$ & $\begin{array}{l}\text { Фосфатно-карбо- } \\
\text { натной полидет- } \\
\text { ритовой органики } \\
\text { (органика заме- } \\
\text { щена карбонатом). } \\
\text { Реликты микроор- } \\
\text { ганизмов в об- } \\
\text { ломках известняка } \\
\text { (обломки члени- } \\
\text { ков, лилий-крино- } \\
\text { идей, брахиопо- } \\
\text { дов, мшанок) } \\
\end{array}$ \\
\hline 5 & 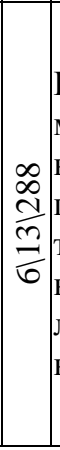 & $\begin{array}{l}\text { Псам } \\
\text { моале } \\
\text { вро- } \\
\text { пели- } \\
\text { товая } \\
\text { вкрап } \\
\text { лен- } \\
\text { ная }\end{array}$ & $\begin{array}{l}\text { менее } 0,01- \\
20 ; \\
0,01-0,1-20 ; \\
0,1-0,25-20 ; \\
0,25-0,5-15 ; \\
0,5-1-15 ; \\
1-2-10 ; \\
2-2,5-1\end{array}$ & $\begin{array}{l}\text { Однород- } \\
\text { ная тон- } \\
\text { козерни- } \\
\text { стая, } \\
\text { участками } \\
\text { неодно- } \\
\text { родная }\end{array}$ & $\begin{array}{l}\text { Кв-10 } \\
\text { Пш-1 }\end{array}$ & $\Gamma+д$ & \begin{tabular}{|l} 
Гидрослюди- \\
сто-углисто- \\
глинистого \\
(каолинит) \\
состава \\
(реакция на \\
Fе положи- \\
тельная)
\end{tabular} & - & - & \begin{tabular}{|l|}
45 \\
(из орга- \\
ногенно- \\
го из- \\
вестняка \\
угловато- \\
окатан- \\
ной фор- \\
мы)
\end{tabular} & $\left|\begin{array}{c}2 \times 2 \\
3,5 \times \\
2\end{array}\right|$ & - & $\begin{array}{l}\text { Фосфатно-карбо- } \\
\text { натной полидет- } \\
\text { ритовой органики } \\
\text { (органика заме- } \\
\text { щена карбонатом). } \\
\text { Реликты микроор- } \\
\text { ганизмов в облом- } \\
\text { ках известняка } \\
\text { (обломки члени- } \\
\text { ков, лилий-крино- } \\
\text { идей, брахиопо- } \\
\text { дов, мшанок) } \\
\end{array}$ \\
\hline
\end{tabular}

Примечание. Условные обозначения колонок: 1 - № п/п; 2 - № шлифа; 3 - петрографическая структура; 4 - фракционный состав, \%; 5 - текстура цемента; 6 - качественный состав песка, \%; 7 - состав формовочной массы; 8 - природа цемента; 9 - содержание шамота, \%; 10 - размер шамота, мм; 11 - содержание дресвы, \%; 12 - размер дресвы, мм; 13 - объем пор, \%; 14 - органическая примесь, мм. Условные обозначения в ячейках: кв - кварц; $п и$ - полевые шпаты; $о$ (н) - органика (навоз); $\partial$ - дресва; $u$ - шамот.

Исходная глина была довольно запесоченной (табл. 1). Содержание песка в шлифе доходит до $60 \%$. Песок представлен в основном кварцем (от 5 до 30\%) (рис. 1: 7).

Кроме этого в составе песка отмечены полевые шпаты - 1-2\% (рис. 2: 5), обломки песчаников, окремненных сланцев и эпидот. Песок большей частью представлен очень мелким «пылевидным» (до 1 мм). Равномерное распределение песка по площади шлифа, размерность и процент содержания его в глине дает возможность определить песок естественной примесью. Запесоченность и ожелезненность являются основными характеристиками гидрослюд.

Формовочные мaсcы. Текстура шлифа петрографами читается как однородная, участками сгустковатая гнездовидно-вкрапленная, неоднородная что, по всей видимости, означает добавление в исходную глину искусственных компонентов. Зафиксировано три рецепта формовочной массы: глина+дресва (органогенный известняк+органика (навоз) (6 фр.), глина+шамот+дресва+органика (навоз) (3 фр.), глина+дресва (органогенный известняк) (7 фр.).

Из неорганических наполнителей в формовочных массах была выявлена дресва (табл. 1; рис. 1-3) и в трех случаях шамот (табл. 1, рис. 3). Дресва в формовочной массе образцов представлена органогенным, окремненным известняком биоморфного состояния. Органика фиксируется петрографами, как окремненные пустоты, остроугольной, неправильной, со сглаженными углами формы, образования. Состав органики определен, как карбонатно-кремнистый или карбонатно-фосфатный и представлен обломка- 
ми известняка, который состоит из известковых органических (биогенных) остатков, сложенных из реликтов раковин фораминифер или фузулин (нижн. пермь, артинский ярус), обломков морских беспозвоночных (мшанки, криноидеи (морские лилии),
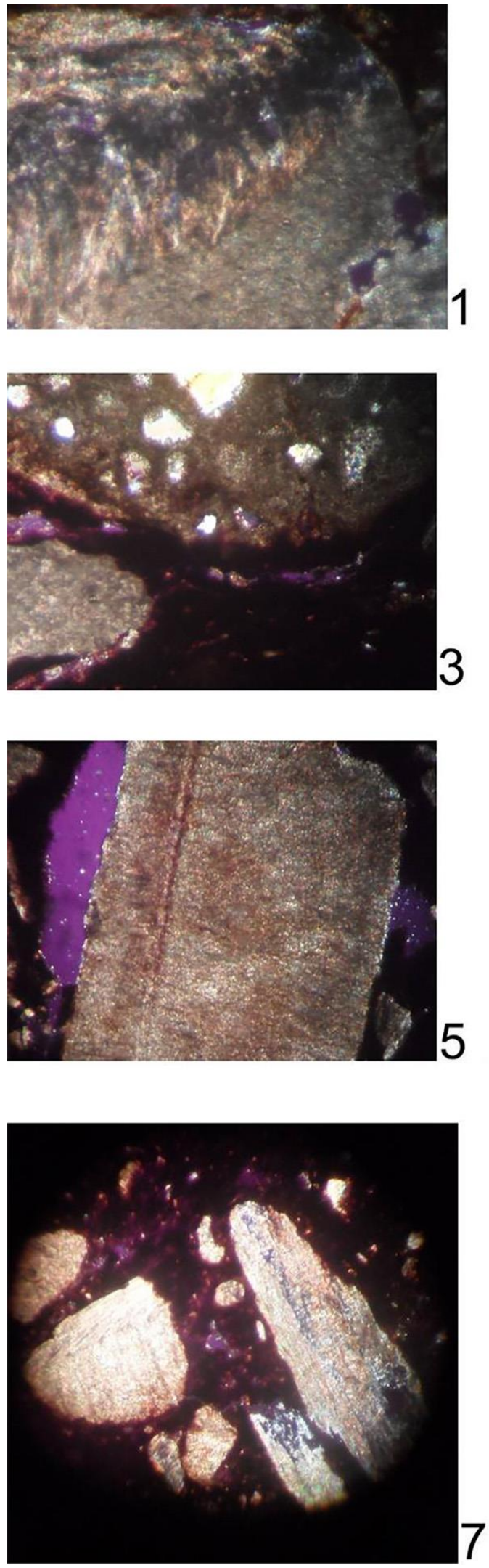

Рисунок 1 - Поселение Токсанбай. Петрографические шлифы.

$$
1 \text { - фрагмент органики (реликты мшанок); }
$$

2 - угловато-окатанные слюдисто-кремнисто-карбонатные (известковые) обломки (дресва); 3- зерно шамота и обломок известняка с биоморфной органикой (дресва);

4, 5- обломки органогенного известняка (многослойных стенок раковин брахиопод и фораминифер) (дресва); 6- поперечное сечение раковины остракоды; 7- кварц; 8- обломок стенки раковины фораминиферы 

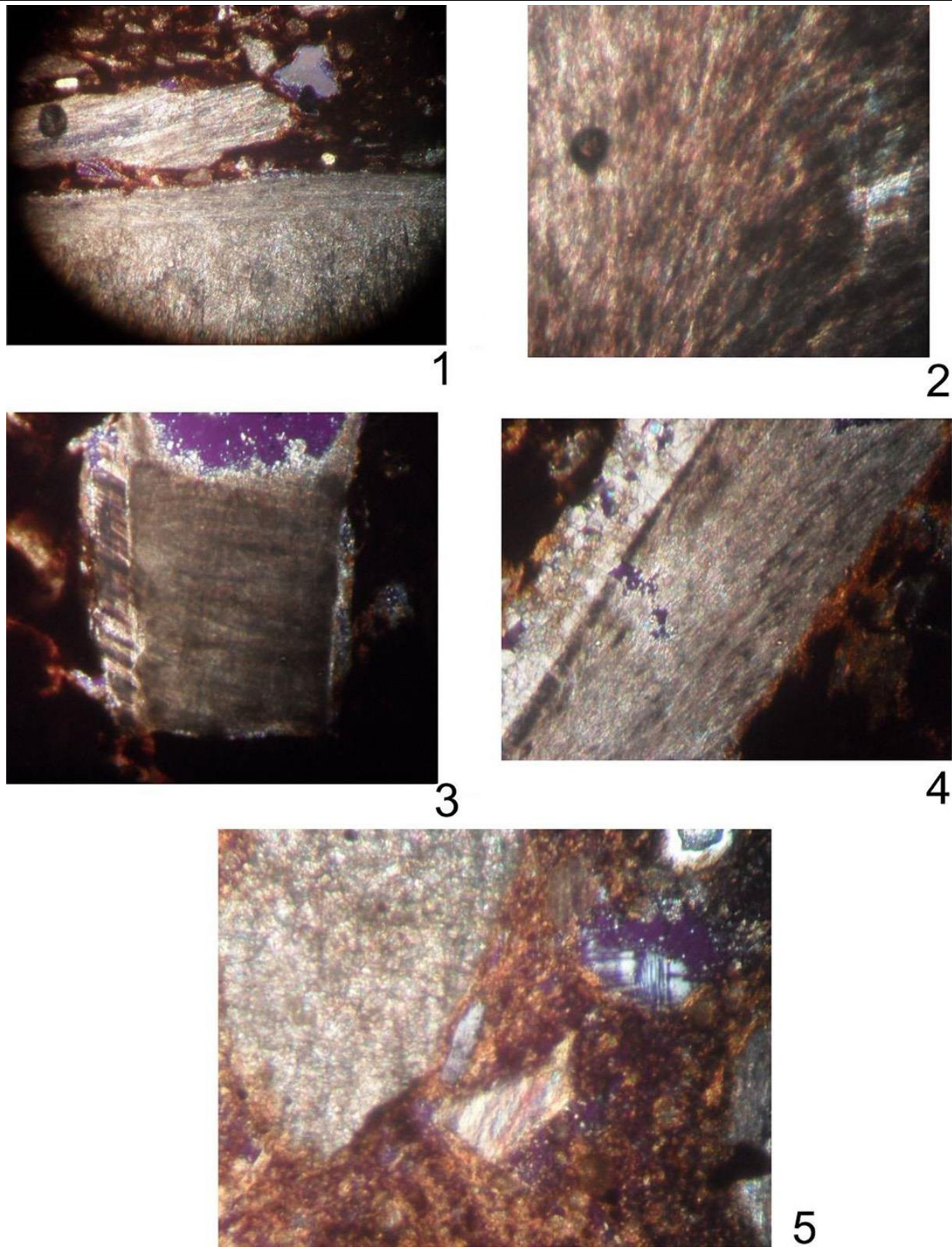

Рисунок 2 - Поселение Токсанбай. Петрографические шлифы.

1 - обломок раковины брахиоподы; 2- раковина брахиопода; 3, 4- обломки карбонатного состава двухслойных раковин брахиопод и стенки раковины фораминифер (дресва); 5- полевой шпат

При взаимодействии органогенного известняка с соляной кислотой наблюдается образование пены с выделением газов, что позволило определить карбонатный состав органики. Анализ с применением молибдена аммония $\left(\mathrm{MoH}_{4}\right)_{2} \mathrm{AmO}_{4}$ показал присутствие в образцах органики фосфатного типа. Органогенный известняк хорошо фиксируется как петрографами, так и при бинокулярном исследовании и даже просто невооруженным глазом. Размер обломков при этом колеблется от пылевидных включений до 3,5 мм длиной. Форма частиц чаще всего округлая, остроугольная, удлиненная, окатанная. Содержание в шлифах - до $50 \%$.

Шамот представлен обломками, подквадратной и подпрямоугольной, неправильной формы, светлого цвета (рис. 3: 4, 5). Размер частиц шамота 0,8-4 мм. Содержание его в образце незначительно (до 10\%).
Шамот сходный по составу с изучаемой керамикой. Добавление крупного шамота в небольшом количестве (до 10\%) связано с усилением термостойкости сосудов. Шамот, так же как и дресва увеличивает огнестойкость изделий [13, с. 90; 14, с. 23].

Из органических наполнителей у части исследуемых образцов были выявлены, при визуальном и бинокулярном осмотре на образцах пустоты округлой, удлиненной и овальной формы от выгоревшей органики. Объем пор занимает до 10\% шлифа. Размер пустот от 0,01 до 8 мм. Выгоревшая органика предположительно определена, как навоз скота. Экскременты животных играли большую роль в уменьшении отрицательного влияния усадки глины на изделие во время сушки и обжига и являлись пластификатором, особенно важно это в отношении запесоченных гидрослюдистых глин [13, с. $102 ; 14$, с. 30; 15; 16$]$. 

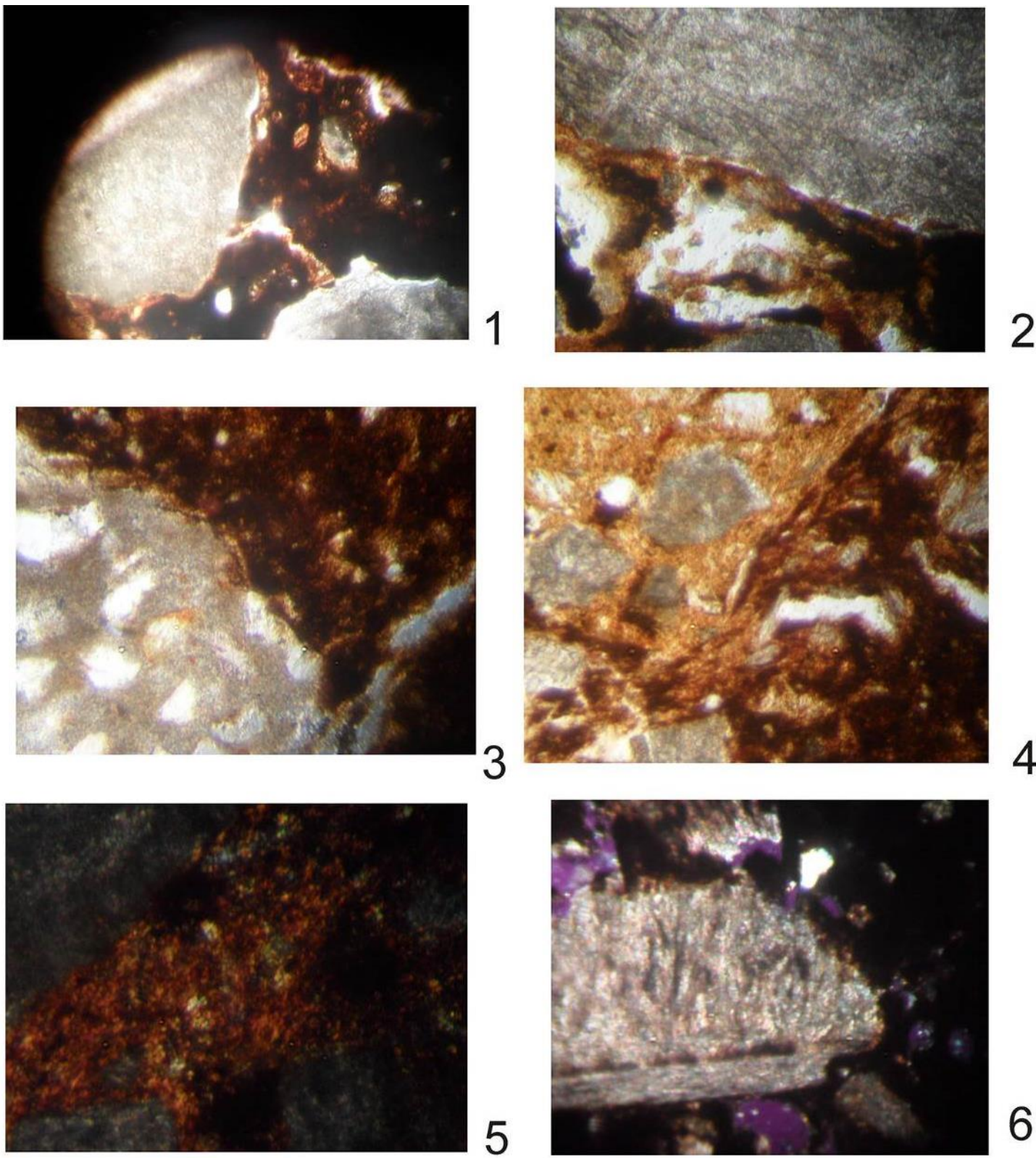

6
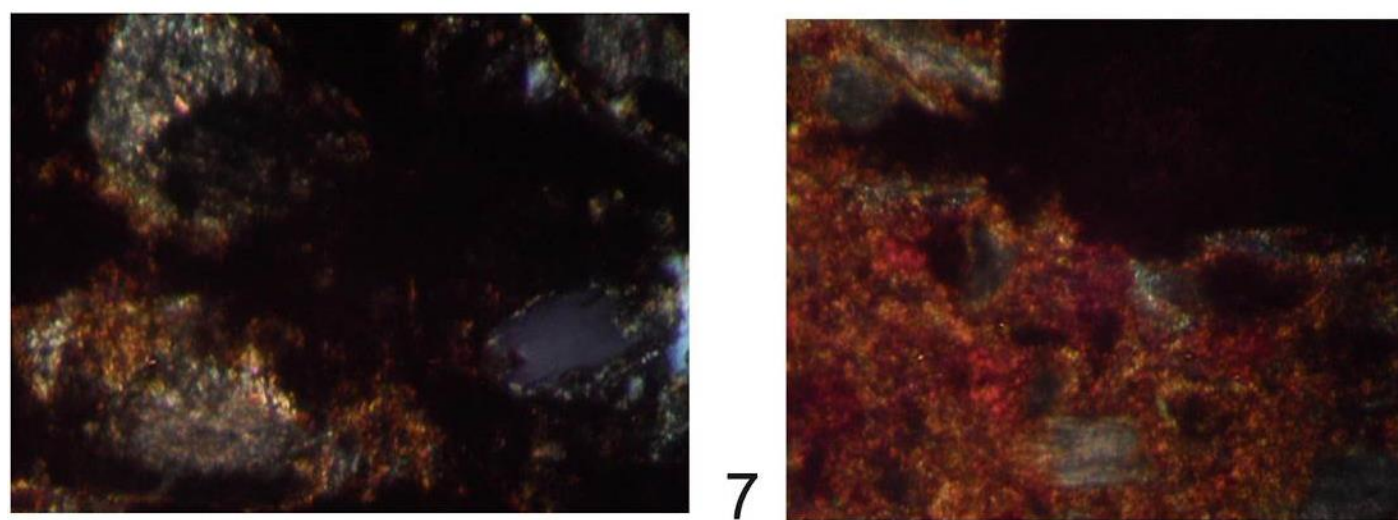

Рисунок 3 - Поселение Токсанбай. Петрографические шлифы.

1 - обломки органогенного известняка и реликты микроорганизмов в нем в биоморфном состоянии (дресва); 2 - обломки органогенного известняка и реликты микроорганизмов в нем в биоморфном состоянии (обломки члеников и криноидей (морских лилий)) (дресва);

3- обломок песчаника глинисто-кварцевого-карбонатного состава; 4, 5- обломки шамота; 6, 7- реликтовый фрагмент створки брахиоподы в обломке известняка (дресва);

8- мелкие обломки реликтов органики в цементе (брахиоподы, мшанки, криноидеи (морские лилии))

В заключении заметим, что исследование древней керамики будет продолжено, но уже сейчас можно сказать, что токсанбайские гончары использовали местную глину, а самой распространенной примесью является местный органогенный известняк, находящийся на плато Устюрт в избытке. 


\section{СПИСОК ЛИТЕРАТУРЫ:}

1. Круг О.Ю. Применение петрографии в археологии // Археология и естественные науки. М., 1965. C. $146-151$.

2. Жущиховская И.С., Залищак Б.Л. Петрографический метод в изучении древней керамики (на материале неолитических средневековых культур Приморья) // Методы естественных наук в археологическом изучении древних производств на Дальнем Востоке СССР. Владивосток, 1986. С. 55-67.

3. Самашев 3., Ермолаева А.С., Тепловодская Т.М. Исследования поселения эпохи палеометалла Токсанбай в Арало-Каспийском междуморье // Комплексные общества Центральной Евразии в III-I тыс. до н.э. Региональные особенности в свете универсальных моделей: мат-лы междунар. конф. (25 августа - 2 сентября 1999 г.). Челябинск - Аркаим: Издво Челябинского госуниверситета, 1999. С. 178-185.

4. Самашев 3.С., Ермолаева А.С., Лошакова Т.Н. Поселение эпохи палеометалла Северо-Восточного Прикаспия // Вопросы истории и археологии Западного Казахстана. Уральск: Западно-Казахстанский центр истории и археологии, 2004. Вып. 3. С. 125153.

5. Самашев 3., Ермолаева А.С., Лошакова Т.Н. Поселения токсанбайского типа на северо-восточном Устюрте // Проблемы изучения культур раннего бронзового века степной зоны восточной Европы: сб. научных трудов. Оренбург: Изд-во ОГПУ, 2009. C. $159-167$.

6. Лошакова Т. Поселенческие комплексы эпохи бронзы северо-восточного Устюрта // Новые материалы и методы археологического исследования: матлы II междунар. конф. молодых ученых. М.: ИА PAH, 2013. C. 78-79.

7. Самашев 3.С., Ермолаева А.С., Лошакова Т.Н. Орудия труда и медеплавильное производство посе-

ления Токсанбай (Северный Устюрт) // XV Уральское археологическое совещание: тез. докл. междунар. археол. конф. Оренбург, 2001. С. 109-110.

8. Самашев 3., Ермолаева А.С., Лошакова Т. К вопросу о культурной принадлежности домостроительных традиций на поселении Токсанбай // Историко-культурное наследие Арало-Каспийского региона: мат-лы II междунар. науч.-практ. конф. (26-28 августа 2010 г.). Актау, 2010. С. 47-55.

9. Лошакова Т.Н. Псалии поселения Токсанбай // Культурогенез позднего бронзового века Волго-Уралья: мат-лы междунар. конф. Самара, 2014. С. 81-88.

10. Шевнина И.В., Лошакова Т.Н. Керамика из жилищ с поселения Токсанбай // VII Исторические чтения памяти Михаила Петровича Грязнова. Омск, 2008. C. $270-278$.

11. Гребенщиков А.В., Деревянко Е.И. Гончарство древних племен Приамурья. Новосибирск, 2001. $120 \mathrm{c}$.

12. Мыльникова Л.Н. Гончарство неолитических племен Нижнего Амура. Новосибирск: ИАиЭ СО PAH, 1999. $160 \mathrm{c}$.

13. Бобринский А.А. Гончарство Восточной Европы. М.: Наука, 1978. 272 с.

14. Глушков И.Г. Керамика как археологический источник. Новосибирск: ИАЭт СО РАН, 1996. 328 с.

15. Бобринский А.А. Гончарная технология как объект // Актуальные проблемы изучения древнего гончарства (коллективная монография). Самара, 1999. C. 75-106.

16. Цетлин Ю.Б. Основные направления и подходы к изучению органических примесей в древней керамики // Актуальные проблемы изучения древнего гончарства: коллективная монография. Самара, 1999. C. $110-140$

Работа выполнена в рамках государственного заказа по бюджетной программе, иифр 1821/ГФ4.

\title{
SOME RESULTS OF PETROGRAPHIC STUDIES OF CERAMICS FROM THE SETTLEMENT TOKSANBAY
}

(C) 2017

\author{
Shevnina Irina Victorovna, researcher of Archaeological Laboratory \\ Kostanay State University named after A. Baitursynov (Kostanay, Republic of Kazakhstan) \\ Loshakova Tatyana Nikolaevna, senior researcher \\ A.Kh. Margulan Institute of Archaeology (Almaty, Republic of Kazakhstan)
}

Abstract. The research is devoted to the studies of raw materials and molding masses of ceramic products from the settlement Toksanbay. The purpose of the research was to study the technological aspects taking place in the course of ceramic vessels production, as well as in-depth study of the raw materials and molding masses of pottery ceramics of the settlement. During the research of samples, in addition to petrographic analysis, fragments of ceramics were studied using the binocular microscopy method, chemical experiments were carried out (using a micromethod) with the use of ammonium molybdenum, hydrochloric acid, and microenacts were checked for iron in the composition of the crock. The received result revealed that as the raw material ferruginous clay was used, and the chemical reaction to $\mathrm{Fe}$ of all fragments turned out to be positive. The original clay contains sand, besides this, sand feldspars, fragments of sandstones, silicified schists and epidote are noted in the sand composition. Three recipes of molding masses were revealed. The organics is stated in the form of silicified voids. The composition of organic matter showed carbonate-siliceous or carbonate-phosphate. The microreaction analysis using ammonium molybdenum $\left(\mathrm{MoH}_{4}\right)_{2} \mathrm{AmO}_{4}$ determined the presence of a phosphate type in organic samples. From the organic fillers, a part of the studied samples revealed hollows of round and oval shape from the burnt organics. The study of the pottery of the settlement will be continued but it can be argued that the Toksanbay potters used local clay, and the most common impurity was organogenic limestone.

Keywords: settlement; Toksanbay; Ustyurt plateau; cliff; molding mass; ceramics; technical and technological analysis; petrographic analysis; binocular microscopy; ammonium molybdenum; carbonate; microreaction; ferruginous clay; feldspar; organogenic limestone; silicified shales; gruss; epidote; thin section; natural admixture; hydromica; recipe of molding mass; shell relic; biogenic residues; sponge spicules; brachiopods. 